\title{
PHYSICAL ACTIVITY OF THE STUDENTS FROM UNIVERSITIES IN BIAŁA PODLASKA IN THEIR FREE TIME ACCORDING TO THE CHOSEN FACULTIES
}

\author{
Ewelina Niźnikowska, Ewa Stępień
}

\author{
Pope John Paul II State School of Higher Education in Biała Podlaska
}

Niźnikowska E., Stępień E. (2015), Physical activity of the students from universities in Biała Podlaska in their free time according to the chosen faculties. Health Problems of Civilization, 2 (9), p. 13-18.

\begin{abstract}
Summary: The aim of the research was to acquire knowledge about students' physical activity in their free time according to their chosen faculties. Subject of the research were the students from seven faculties in two universities from Biała Podlaska: computer science, public health, medicine, nursing, tourism and recreation, physiotherapy and PE (physical education) - 548 people in total were the participants. In the work, the method of diagnostic survey based upon the questionnaire technique was applied.

Faculty is the aspect that has great impact on the type of chosen forms of physical activities, reasons of its choice, barrier and importance of physical activities in the participants' lives. Students from such faculties as PE and tourism and recreation show more physical activity in contrast to students from other faculties. More attention should be paid to extension and promotion of physical activity - a very important part of healthy lifestyle - in didactical-educational work of universities.
\end{abstract}

Keywords: physical activity, free time, students, faculty, universities of Biała Podlaska

\section{Introduction}

Physical activity is observed to be the most preferable form of spending free time taking into account its important role in health. There have been a lot of researches of the role of physical activities in the health preservation of society conduced in Poland and abroad for many years. (Bouchard i in. 2007, Haskell i in. 2007, Sygit 2008, Baumann i in. 2009, Mogiła - Lisowska 2010, Mynarski i in. 2012).

A lot of researches have shown that a large proportion of society leads a sedentary life that has bad influence on health. (Palica i in. 2010, Sochocka - Wojtyłko 2013). Studies undertaken in Poland suggest that regular physical activity among adults is a deal of directly marginal group of people and is estimated on a level of 10\%. (Polish National Health Program 1996). Hence one of the most important operational goals of Polish National Health Program in 2007-2015 is to increase the level of physical activity of population. On the other hand, according to Drygas (2010) data resulting from the study of public opinion by Eurobarometer revealed that the physical activity of Polish society does not depart from the activity of citizens from the majority of European countries. A decrease of physical activity in older groups compared to the young is observed in many countries of European Union. (Nowak - Starz 2007, Wojtyniak, Goryński 2008). A similar situation is confirmed by all-Polish research Natpol in which it was noted that the lowest regular physical activity has been observed among people in the age group from 18 to 39 years old.

In scientific literature the age from 20 to 24 is known as the last phase of the youth period. This is a time of the top physical condition and capability to back a high level of motor functions. Performed exercises are characterized by high effectiveness and their skillful adaptation to activities related to science, work, and participation in sport and different forms of physical activities. This is also a time of final formation of typical habits and healthful basis due to which it would be possible to function in everyday adulthood. According to Corbin, ect. (2007) people at this age are less active than they were in middle school. During the time of the last two months of studying, $66 \%$ of pupils were added to the group that took up intensive physical activities. Instead, during a couple of the first months of studying in high school there were only $44 \%$ of pupils added to the same group.

Address for correspondence: Ewelina Niźnikowska, Pope John Paul II State School of Higher Education in Biała Podlaska, Office of Tourism and Recreation (Zakład Turystyki i Rekreacji), Sidorska 95/97, 21-500 Biała Podlaska, phone: +48 83 344 99 02, e-mail: rewela.n@op.pl

Tables: 6 Figures: 0 References: 21 Full-text PDF www.hpc.edu.pl Copyright (C) Pope John Paul II State School of Higher Education in Biała Podlaska, Sidorska 95/97, 21-500 Biała Podlaska Indexation: Index Copernicus, AGR0, ProQuest, Polish Medical Bibliography, Polish Ministry of Science and Higher Education. This is an open-access article distributed under the terms of the Creative Common Attribution Non-commercial license (http://creativecommons.org/licenses/by-nc/3.0), which permits use, distribution and reproduction in any medium, provided the original works is properly cited, the use is non-commercial and is otherwise in compliance with the license. 
Young students must be aware of the influence of physical activities on health. Physically active students claim that they have a higher level of energy and lower level of stress and weariness than non-active students. (Corbin and others 2007). Although conducting physical activity by students is conditioned by a number of factors: amount of free time, schedule of classes at school, tiredness or place of residence as well as habits carried out from home, it seems reasonable to gather information about their physical activity. The goal of the research was to gain knowledge about physical activity of students in their free time according to chosen courses. An equal goal was also to discover the forms of physical activity, its grounds and barriers as well as its importance in students' lives.

\section{Materials and methods}

548 people took part in the research: 327 women and 221 men that were studying at Pope John Paul II State School of Higher Education in Biała Podlaska and the Faculty of Physical Education and Sports in Biała Podlaska.

Subject of the research were the students from seven faculties at two universities from Biała Podlaska: computer science, public health, medicine, nursing, tourism and recreation, physiotherapy and PE (physical education). Table 1 depicts particular characteristics of research material.

Table 1. Characteristics of student-respondents

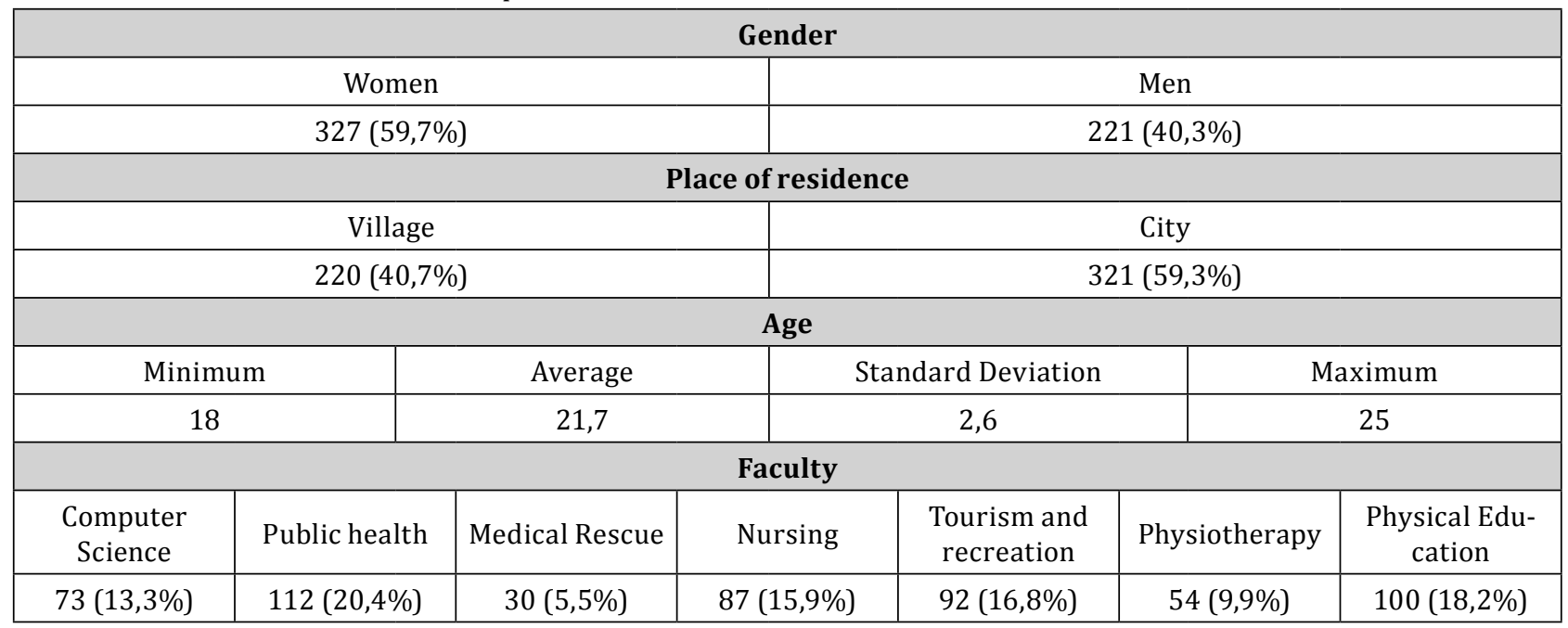

In the project a method of diagnostic survey based upon the questionnaire technique was used. Statistical analysis was carried out on the basis of the program STATISTICA version 7.1. The percentage structure analysis of empirical schedules was used for statistical description. Statistical conclusion is done with the help of Pearson's chi-square test for quantitative variables and non-parametric Kruskal-Wallis test (H) for estimation of discrepancy of qualitative variables. In all studied cases the accepted level of essentiality was p=0,05.

\section{Research findings}

The students who participated in the research were asked to determine number of hours per week dedicated to physical activities in their free time (tab. 2). It was reported that students of PE (39,0\%) and tourism and recreation $(15,2 \%)$ faculties spend 9 or more hours per week on physical activities. Students from medical faculty mostly pointed out 4-6 hours per week devoted to physical activities. Whereas students from computer science and nursing faculties spent only 1-2 hours per week, that is respectively: $28,8 \%$ and $43,7 \%$.

Based upon the undertaken studies a high dependency of asserted physical activity of respondents on the faculty $(H=105,50, p<0,05)$ was observed. Extensive analysis has shown an appreciable difference between students from PE course and the other ones. Also there was a difference between students of tourism and recreation faculty and students from public health and nursing faculties. 
Table 2. Number of hours per week that respondents spend on physical activities in their free time $(\mathrm{n}=548)$

\begin{tabular}{|c|c|c|c|c|c|c|c|c|c|}
\hline & $\mathrm{CS}$ & $\mathrm{PH}$ & MR & $\mathrm{N}$ & TR & PH. & $\mathrm{PE}$ & $\mathrm{H}$ & $\mathrm{p}$ \\
\hline $1-2 \mathrm{~h}$ & $28,8 \%$ & $33,9 \%$ & $30,0 \%$ & $43,7 \%$ & $22,8 \%$ & $22,2 \%$ & $6,0 \%$ & \multirow{5}{*}{105,50} & \multirow{5}{*}{$0,0000^{*}$} \\
\hline $2-4 \mathrm{~h}$ & $20,5 \%$ & $39,3 \%$ & $16,7 \%$ & $26,4 \%$ & $28,3 \%$ & $38,9 \%$ & $14,0 \%$ & & \\
\hline $4-6 \mathrm{~h}$ & $24,7 \%$ & $18,8 \%$ & $40,0 \%$ & $20,7 \%$ & $19,6 \%$ & $25,9 \%$ & $15,0 \%$ & & \\
\hline $6-8 \mathrm{~h}$ & $20,5 \%$ & $6,3 \%$ & $3,3 \%$ & $4,6 \%$ & $14,1 \%$ & $3,7 \%$ & $26,0 \%$ & & \\
\hline $\begin{array}{l}9 \text { and } \\
\text { more }\end{array}$ & $5,5 \%$ & $1,8 \%$ & $10,0 \%$ & $4,6 \%$ & $15,2 \%$ & $9,3 \%$ & $39,0 \%$ & & \\
\hline
\end{tabular}

An important feature in realization of objectives was obtaining of information about the most useful forms of physical activities among respondents in their free time (tab. 3).

Table 3. Asserted forms of physical activity of respondents in their free time $(n=548)$

\begin{tabular}{|c|c|c|c|c|c|c|c|c|c|}
\hline & $\mathrm{CS}$ & $\mathrm{PH}$ & $\mathrm{MR}$ & $\mathrm{N}$ & $\mathrm{TR}$ & $\mathrm{PH}$ & $\mathrm{PE}$ & $\mathrm{Chi}^{2}$ & $\mathrm{p}$ \\
\hline Walking & $68,5 \%$ & $94,6 \%$ & $66,7 \%$ & $85,1 \%$ & $60,9 \%$ & $77,8 \%$ & $36,0 \%$ & 102,42 & $0,0000^{*}$ \\
\hline Running & $47,9 \%$ & $38,4 \%$ & $63,3 \%$ & $57,5 \%$ & $41,3 \%$ & $40,7 \%$ & $53,0 \%$ & 13,83 & $0,0316^{*}$ \\
\hline Cycling & $60,3 \%$ & $76,8 \%$ & $56,7 \%$ & $78,2 \%$ & $46,7 \%$ & $66,7 \%$ & $44,0 \%$ & 43,67 & $0,0000^{*}$ \\
\hline Team games & $45,2 \%$ & $10,7 \%$ & $43,3 \%$ & $16,1 \%$ & $47,8 \%$ & $31,5 \%$ & $58,0 \%$ & 77,31 & $0,0000^{*}$ \\
\hline Fitness & $8,2 \%$ & $25,9 \%$ & $10,0 \%$ & $19,5 \%$ & $29,3 \%$ & $1,9 \%$ & $37,0 \%$ & 40,81 & $0,0000^{*}$ \\
\hline Swimming & $32,9 \%$ & $33,0 \%$ & $26,7 \%$ & $21,8 \%$ & $48,9 \%$ & $51,9 \%$ & $42,0 \%$ & 23,01 & $0,0008^{*}$ \\
\hline
\end{tabular}

The most popular forms of physical activities in the free time among students from majority of Universities in Biała Podlaska are walks, cycling and running. Students from physiotherapy faculty prefer swimming, whereas students of nursing faculty do this less often. Fitness is chosen by students from PE faculty, less often - by students from physiotherapy and computer science faculties. Type of faculty is the parameter that has statistically great impact on the choice of the form of physical activity.

The main reason for participation in physical activity of respondents from all faculties is improvement of condition from 72,6\% (computer science faculty) up to 90, 2\% (faculty of public health) (tab. 4). Maintaining healthy lifestyle is the reason that motivates students mostly from faculties of public health as well as of tourism and recreation.

Competitive career was indicated by respondents from all facultys as the least important reason. Type of faculty is also the parameter that decides for the reasons for becoming physically active among respondents. Statistical analysis has shown a significant dependence between reasons for being active, such as condition improving $\left(\mathrm{Chi}^{2}=13,03 ; \mathrm{p}<0,05\right)$ and competitive career $\left(\mathrm{Chi}^{2}=41,71 ; \mathrm{p}<0,001\right)$, and the given faculty.

Table 4. Reasons for respondents to be physically active $(n=548)$

\begin{tabular}{|c|c|c|c|c|c|c|c|c|c|}
\hline & $\mathrm{CS}$ & $\mathrm{PH}$ & $\mathrm{MR}$ & $\mathrm{N}$ & $\mathrm{TR}$ & $\mathrm{PH}$ & $\mathrm{PE}$ & $\mathrm{Chi}^{2}$ & $\mathrm{p}$ \\
\hline $\begin{array}{c}\text { Creation of healthy } \\
\text { lifestyle }\end{array}$ & $60,3 \%$ & $70,5 \%$ & $46,7 \%$ & $54,0 \%$ & $68,5 \%$ & $55,6 \%$ & $65,0 \%$ & 11,88 & 0,0646 \\
\hline $\begin{array}{c}\text { Condition improve- } \\
\text { ment }\end{array}$ & $72,6 \%$ & $90,2 \%$ & $76,7 \%$ & $82,8 \%$ & $87,0 \%$ & $81,5 \%$ & $87,0 \%$ & $\mathbf{1 3 , 0 2}$ & $\mathbf{0 , 0 4 2 7} *$ \\
\hline Entertainment & $53,4 \%$ & $51,8 \%$ & $50,0 \%$ & $52,9 \%$ & $54,3 \%$ & $57,4 \%$ & $54,0 \%$ & 0,66 & 0,9953 \\
\hline Sport career & $2,7 \%$ & $0,9 \%$ & $6,7 \%$ & $5,7 \%$ & $16,3 \%$ & $7,4 \%$ & $23,0 \%$ & $\mathbf{4 1 , 7 1}$ & $\mathbf{0 , 0 0 0 0} *$ \\
\hline $\begin{array}{c}\text { Improvement of body } \\
\text { resistance }\end{array}$ & $53,4 \%$ & $58,9 \%$ & $60,0 \%$ & $57,5 \%$ & $54,3 \%$ & $48,1 \%$ & $56,0 \%$ & 2,28 & 0,8922 \\
\hline
\end{tabular}

Detailed research results concerning barriers for participation in physical activity of respondents are presented in table 5 . 
Table 5. Barriers for participation in physical activity of the respondents $(n=548)$

\begin{tabular}{|c|c|c|c|c|c|c|c|c|c|}
\hline & $\mathrm{CS}$ & $\mathrm{PH}$ & $\mathrm{MR}$ & $\mathrm{N}$ & $\mathrm{TR}$ & $\mathrm{PH}$ & $\mathrm{PE}$ & $\mathrm{Chi}^{2}$ & $\mathrm{p}$ \\
\hline $\begin{array}{c}\text { Lack of organizational } \\
\text { skills }\end{array}$ & $15,1 \%$ & $21,4 \%$ & $30,0 \%$ & $17,2 \%$ & $39,1 \%$ & $18,5 \%$ & $24,0 \%$ & $\mathbf{1 8 , 9 9}$ & $\mathbf{0 , 0 0 4 2} *$ \\
\hline Lack of time & $60,3 \%$ & $51,8 \%$ & $60,0 \%$ & $82,8 \%$ & $35,9 \%$ & $72,2 \%$ & $60,0 \%$ & $\mathbf{4 7 , 1 0}$ & $\mathbf{0 , 0 0 0 0 *}$ \\
\hline Lack of willingness & $41,1 \%$ & $46,4 \%$ & $43,3 \%$ & $32,2 \%$ & $44,6 \%$ & $31,5 \%$ & $35,0 \%$ & 7,75 & 0,2568 \\
\hline $\begin{array}{c}\text { Lack of proper sports } \\
\text {-recreational infra- } \\
\text { structure }\end{array}$ & $31,5 \%$ & $33,9 \%$ & $40,0 \%$ & $31,0 \%$ & $43,5 \%$ & $37,0 \%$ & $29,0 \%$ & 5,94 & 0,4294 \\
\hline Lack of funds & $49,3 \%$ & $53,6 \%$ & $53,3 \%$ & $36,8 \%$ & $57,6 \%$ & $35,2 \%$ & $65,0 \%$ & $\mathbf{2 2 , 3 3}$ & $\mathbf{0 , 0 0 1 1}$ \\
\hline Excess of home duties & $41,1 \%$ & $46,4 \%$ & $23,3 \%$ & $49,4 \%$ & $25,0 \%$ & $57,4 \%$ & $25,0 \%$ & $\mathbf{3 3 , 4 1}$ & $\mathbf{0 , 0 0 0 0} *$ \\
\hline Additional work & $26,0 \%$ & $19,6 \%$ & $10,0 \%$ & $14,9 \%$ & $28,3 \%$ & $14,8 \%$ & $26,0 \%$ & 10,85 & 0,0931 \\
\hline
\end{tabular}

Among the barriers for participation in physical activities of respondents the following were indicated: lack of time - faculty of computer science $(60,3 \%)$, faculty of medicine $(60,0 \%)$, nursing $(82,8 \%)$, faculty of physiotherapy $(72,2 \%)$ or lack of funds - faculty of public health $(53,6 \%)$, faculty of tourism and recreation $(57,6 \%)$, faculty of PE $(65,0 \%)$. These are some of the barriers, beside lack of organizational skills and excess of household duties, participation in which changes according to faculty.

When analyzing the meaning of physical activity in respondents' life considerable differences according to chosen faculty were found (tab. 6).

Table 6. Meaning of physical activity in respondents' life ( $n=548)$

\begin{tabular}{|c|c|c|c|c|c|c|c|c|c|}
\hline & $\mathrm{CS}$ & $\mathrm{PH}$ & $\mathrm{MR}$ & $\mathrm{N}$ & $\mathrm{TR}$ & $\mathrm{PH}$ & $\mathrm{PE}$ & $\mathrm{Chi}^{2}$ & $\mathrm{p}$ \\
\hline $\begin{array}{c}\text { Enables contact with } \\
\text { other people }\end{array}$ & $63,0 \%$ & $81,3 \%$ & $70,0 \%$ & $74,7 \%$ & $68,5 \%$ & $42,6 \%$ & $70,0 \%$ & $\mathbf{2 8 , 1 6}$ & $\mathbf{0 , 0 0 0 1}^{*}$ \\
\hline Enables rest & $76,7 \%$ & $83,0 \%$ & $60,0 \%$ & $79,3 \%$ & $59,8 \%$ & $27,8 \%$ & $58,0 \%$ & $\mathbf{6 5 , 5 2}$ & $\mathbf{0 , 0 0 0 0}$ \\
\hline $\begin{array}{c}\text { Provides entertain- } \\
\text { ment }\end{array}$ & $56,2 \%$ & $48,2 \%$ & $76,7 \%$ & $46,0 \%$ & $45,7 \%$ & $24,1 \%$ & $44,0 \%$ & $\mathbf{2 4 , 9 9}$ & $\mathbf{0 , 0 0 0 3} *$ \\
\hline $\begin{array}{c}\text { Enables own develop- } \\
\text { ment }\end{array}$ & $49,3 \%$ & $25,9 \%$ & $53,3 \%$ & $47,1 \%$ & $58,7 \%$ & $20,4 \%$ & $57,0 \%$ & $\mathbf{4 4 , 1 4}$ & $\mathbf{0 , 0 0 0 0} *$ \\
\hline $\begin{array}{c}\text { Enables realization } \\
\text { of one's interests and } \\
\text { hobbies }\end{array}$ & $42,5 \%$ & $47,3 \%$ & $33,3 \%$ & $35,6 \%$ & $58,7 \%$ & $14,8 \%$ & $60,0 \%$ & $\mathbf{4 1 , 1 0}$ & $\mathbf{0 , 0 0 0 0 *}$ \\
\hline
\end{tabular}

In the opinions of respondents from all chosen faculties, physical activity in their free time allows for the connection with other people - from $27,8 \%$ (faculty of physiotherapy) to $83,0 \%$ (faculty of public health). Statistical analysis has shown a significant dependence between all offered answers concerning the meaning of physical activity in respondents' lives and their faculty.

\section{Discussion}

Physical activity of young students, depending on the faculty, was a subject for analysis for many authors (Sławek 2008, Sygit 2008, Żiżka - Salamon 2008, Winiarska - Mieczan, Dymek 2009, Kijo 2010, Zadarko i in. 2011, Kochanowicz, Handsorfer - Korzon 2013, Sochocka, Wojtyłko 2013). According to Stachur and others (2008) an organization and type of exercises in students' free time depend on his or her preferences, interests, habits, other duties, amount of free time and also financial capacity.

When realizing the statistical analysis it was determined that the faculty differentiates respondents in terms of declared physical activity in their free time. Detailed analysis has shown a substantial dependence between students from faculty of PE and students from another faculties. No doubt an influence on that is due to the specificity of the course in Academy of Physical Education as well as high awareness concerning a positive effect of physical activity on the human organism of these students.

When realizing the analysis from the collected material concerning an estimates of physical activity of respondents in their free time, it was found that students from PE faculty $(39,0 \%)$ and faculty of tourism and recreation $(15,2 \%)$ spend most of their time (more than 9 hours) per week on physical activity. Kijo (2010) who 
analyzed physical activity of the students from public and private schools in Łódź also confirms this research. Author considers that students connected with PE faculty have higher results in physical activities in contrast to odd faculties, and the difference is evident.

The most popular forms of physical activity among students from the majority of faculties in Universities in Biała Podlaska are walks, cycling, running and team games. Similar results were obtained by Sochocka i Wojtyłko (2013) investigating full-time students from medical and non-medical faculties. Their results show that students prefer such forms of physical activity as cycling, team plays, walking with a dog, activities in groups and swimming. To sum up, it is possible to ascertain that respondents generally choose those forms of physical activity that are easily accessible, not expensive and popular.

The other problem was to show the reasons of entering into physical activities. The main reason for respondents to be involved in physical activities was the improvement of condition and creation of healthy lifestyle. The results of our own research are confirmed in the research of Palica and others (2010), who investigated the students from the Universities in Silesia and Lesser Poland. They indicated that the reasons for being physically active are pleasure stemming from the activeness and health benefits. Similar results are also given by Sławek (2008), who investigated the reasons behind physical activeness among students of the University of Lodz. The main reasons for that were health care, physical capacity and willingness to keep good physical condition. According to Żiżki-Salamon (2008), the lower the year of study, the more respondents appreciate the influence of the activeness on improving physical condition. Though the higher the year of study, the more health aspects of activeness are recognized.

The analysis of the results taken from the research presented within the last number of years by different authors (Kijo 2010, Sochocka, Wojtyłko 2013) allows to ascertain that the barriers for participation in physical activities haven't changed in a meaningful way. For the majority of respondents the barriers for participation in physical activities are lack of time and funds. A quite different data was obtained by Sławek (2008). She has proved that the main barriers for participation in physical activities were lack of motivation and laziness.

On the basis of performed research we can also say something about the role of physical activity in respondents' lives. According to the students of all chosen faculties from the Universities in Biała Podlaska physical activeness allows first of all for communication with other people and for relaxation. Though in research by Kochanowicz, Hansdorfer-Korzon (2013) students pointed that physical activities increase sense of well-being and person's appearance.

Collected results oblige us to look for methods of implementation of ways to make young generations physically active.

\section{Conclusions}

1. Faculty is the aspect that has great impact on the type of chosen forms of physical activities, reasons of their choice, barriers and importance of physical activities in the participants' lives.

2. Students from such faculties as PE and tourism and recreation show more physical activity in contrast to students from another faculties.

3. The main reasons for physical activity of respondents from all the chosen faculties are creation of a healthy lifestyle and condition improvement, whereas the barriers are lack of time and funds.

4. More attention ought to be paid to extension and promotion of physical activity - a very important part of healthy lifestyle - in didactical-educational work of universities.

\section{References:}

1. Baumann A., Bull F., Craig C., Ainsworth B., Sallis J., Bowles H., Hagstromer M., Sjostrom M., Pratt M. (2009), The International Prevalence Study on Physical Activity: results from 20 countries. International Journal of Behavioral Nutrion and Physical Activity.

2. Bouchard C., Blair S., Haskell W. (2007), Why study physical activity and health, In: W. Bouchard, S. Blair, W. Haskell (eds.), Physical Activity and Health, Human Kinetics, Champaign.

3. Corbin Ch., Welk G., Corbin W., Welk K. (2007), Fitness i wellness. Kondycja, sprawność zdrowie. Zysk i S-ka, Poznań.

4. Haskell W., Lee I., Pate R., Powell K., Blair S., Franklin B., Macera C., Heath G., Thompson P., Baumann A. (2007), Physical Activity and Public Health. Update Recommendation for Adults from the American College of Sports Medicine and the American Heart Association. Circulation, 116, p. 1081-1093. 
5. Kijo P. (2010), Aktywność fizyczna wśród studentów kierunków pedagogicznych łódzkich uczelni publicznych, W: Z. Barabasz (red.), Aktywność przez całe życie. Zdrowie i sprawność studentów pod kontrola. PWSZ, Krosno, s. $157-180$.

6. Kochanowicz B., Hansdorfer-Korzon R. (2013), Postawy studentów kierunku fizjoterapii wobec aktywności fizycznej. Ann. Acad. Med. Gedan., 43, s. 19-28.

7. Mogiła-Lisowska J. (2010), Rekreacyjna aktywność ruchowa dorosłych Polaków - uwarunkowania i styl uczestnictwa. AWF, Warszawa.

8. Mynarski W., Rozpara M., Królikowska B., Puciato D., Graczykowska B. (2012), Jakościowe i ilościowe aspekty aktywności fizycznej. Studia i Monografie, Oficyna Wydawnicza Politechniki Opolskiej, s. 313.

9. NATPOL 2011. Prognoza sytuacji zdrowotnej Polaków na 2020 rok, http:/www.natpol.pl.

10. Narodowy Program Zdrowia 1996-2005, MEN i MZ, Warszawa.

11. Nowak - Starz G. (2007), Physical development. State of Health and Lifestyle of Children and Adolescents in Poland in relation to social factors. Rivista Italiana Medicina di dell Adolescenza, 5(1), p. 30-36.

12. Palica D., Karkoszka G., Wołkowyska B. (2010), Motywy podejmowania przez studentów aktywności ruchowej. W: Z. Barabasz, E. Zadarko (red.), Aktywność przez całe życie. Zdrowie i sprawność studentów pod kontrola. PWSZ w Krośnie, s. 199-208.

13. Sławek M. (2008), Aktywność ruchowa studentów Uniwersytetu Łódzkiego w czasie wolnym - ważnym elementem jakości zdrowego życia. W: A. Kaźmierczak (red.), Kultura fizyczna i zdrowotna współczesnego człowieka. Teoretyczne podstawy i praktyczne implikacje. Uniwersytet Łódzki, Łódź, s. 167-175.

14. Sochocka L., Wojtyłko A. (2013), Aktywność fizyczna studentów studiów stacjonarnych kierunków medycznych i niemedycznych. Medycyna Środowiskowa, 16(2), s. 53-58.

15. Sport and physical activity, Special Eurobarometr 72.3, European Commission, 2010.

16. Stachura A., Płatek Ł., Benek A. (2008), Aktywność ruchowa kobiet i mężczyzn w różnym wieku. W: A. Kaźmierczak (red.), Kultura fizyczna i zdrowotna współczesnego człowieka. Teoretyczne podstawy i praktyczne implikacje. Uniwersytet Łódzki, Łódź, s. 214-219.

17. Sygit K. (2008), Aktywność fizyczna młodzieży akademickiej. Zeszyty Naukowe Uniwersytetu Szczecińskiego, Prace Instytutu Kultury Fizycznej, 25, s. 15-21.

18. Winiarska-Mieczan A., Dymek T. (2009), Ocena aktywności fizycznej wśród młodzieży akademickiej lubelskich uczelni. Medycyna Sportowa, 2(6), s. 125-131.

19. Wojtyniak B., Goryński P. (2008), Sytuacja zdrowotna ludności Polski. Narodowy Instytut Zdrowia Publicznego, Państwowy Zakład Higieny, Warszawa.

20. Zadarko E., Barabasz Z., Nizioł E. (2011), Ocena poziomu aktywności fizycznej studentek wybranych kierunków medycznych na tle badań populacyjnych. Przegląd Medyczny Uniwersytetu Rzeszowskiego, 2, s. 188-194.

21. Żiżka-Salamon D. (2008), Aktywność sportowo-rekreacyjna studentów Podhalańskiej Państwowej Wyższej Szkoły Zawodowej w Nowym Targu, W: A. Kaźmierczak (red.), Kultura fizyczna i zdrowotna współczesnego człowieka. Teoretyczne podstawy i praktyczne implikacje. Uniwersytet Łódzki, Łódź, s. 176-182.

Submitted: 11.01 .2015

Accepted: 23.03.2015 